\title{
Soil structure of sand quarries territory
}

\author{
Yulia Timofeeva ${ }^{1}$, Elena Sukhacheva ${ }^{1}$, Boris Aparin ${ }^{1}$, Vitaly $_{\text {Terleev }}{ }^{2}$, \\ Aleksandr Nikonorov, ${ }^{2, *}$, Luka Akimov ${ }^{2}$ \\ ${ }^{1}$ The Dokuchaev Central Soil Science Museum, Birzhevoy proezd, 6, St.Petersburg, 199034, Russian \\ Federation \\ ${ }^{2}$ Peter the Great St.Petersburg Polytechnic University, Polytechnicheskaya, 29, St.Petersburg, 195251, \\ Russian Federation
}

\begin{abstract}
Anthropogenic activities are one of the leading factors of soil differentiation. Significant changes in the soil cover occur as a result of the construction of quarries. The mining industry causes the complete degradation of soils in large areas, the change of the natural soil cover and elevation around the quarries, the destruction of vegetation, disturbs biodiversity of the territory and the death of ecosystems. Soil cover structures of mining quarries have been considered on the example of the Leningrad region such as a natural conditions and environmental peculiarities typical for the whole Russian North-West area. Decoding and diagnostic signs of anthropogenic transformed soils were determined. The type and degree of transformation of the component composition, the contrast and heterogeneity of the soil cover, intercomponent connections, the shape and figure of the internal organization of the of soil cover structures have been identified. The complexity of the anthropogenic transformed soils cover is illustrated by "key site".
\end{abstract}

\section{Introduction}

Anthropogenic impact is becoming one of the leading factors in soil changes and the formation of specific forms of soil cover structure (SCS). SCS is the totality of all the uniform heterogeneity of the soil cover. SCS is characterized by the spatial ranges of certain soils that often repeat in space, creating a stable composition and pattern of the soil cover, and stable mechanisms of geochemical and geophysical relationships between soils included in this structure [1-6]. Significant changes in SCS occur as a result of quarrying. The mining industry entails the complete destruction of soils in vast territories and a change in the natural soil cover around quarries.

Leningrad region is a typical ecosystem for the North-West of the Russian Federation. This is a large agricultural region, characterized by a wide variety of soil cover structures. Various minerals are mined in the region. The most common are quarries for the extraction of sand, which are available in each administrative district. The state geological map shows the deposits of sand and gravel material, building sand, glass and molding sand [7].

Despite the fact that sand quarries occupy relatively small areas in the region (about 90 $\mathrm{km} 2$, which is $0.1 \%$ of the region's area) they are the most environmentally disadvantaged

\footnotetext{
* Corresponding author: coolhabit@yandex.ru
} 
territories with the most disturbed soil cover (SC) functions [8]. During the development of quarries, natural resources (soil and water) are withdrawn, vegetation is destroyed, and terrain and hydrogeological conditions change, the biodiversity of the territory and the loss of ecosystems are disrupted [9-10]. A common consequence of this is a change in the values of the resource potential of soils (agricultural, forestry and environmental).

\section{Materials and methods}

The object of study is anthropogenic transformed soils (ATS) formed as a result of mining. Anthropogenic transformed SPS are soil combinations with partially or completely disrupted historical inter-component relationships. Newly formed connections form new SPS over a long period of time. Inception phase SCS is characterized by, at first, inter-component connections correspond to certain types of SCS in natural landscapes. And second, the component composition, ESA shape, and SCS boundaries are radically different from those in natural conditions.

The component composition of the new SCS consists of different degrees of transformed soils and at the initial stages of formation of the SCS does not correspond to the type of SCS by the nature of the connections. This discrepancy is minimized over time.

According to the typology of anthropogenic transformed SCS developed in [8], such areas are characterized by the mining type of SCS. It is possible to decipher the quarry territory by the presence on the satellite image of one or several rounded bright spots of significant size (up to several $\mathrm{km} 2$ ) with clear uneven borders and often with a radially concentric surface pattern. Especially well decrypted quarries filled with water (Fig. 1).

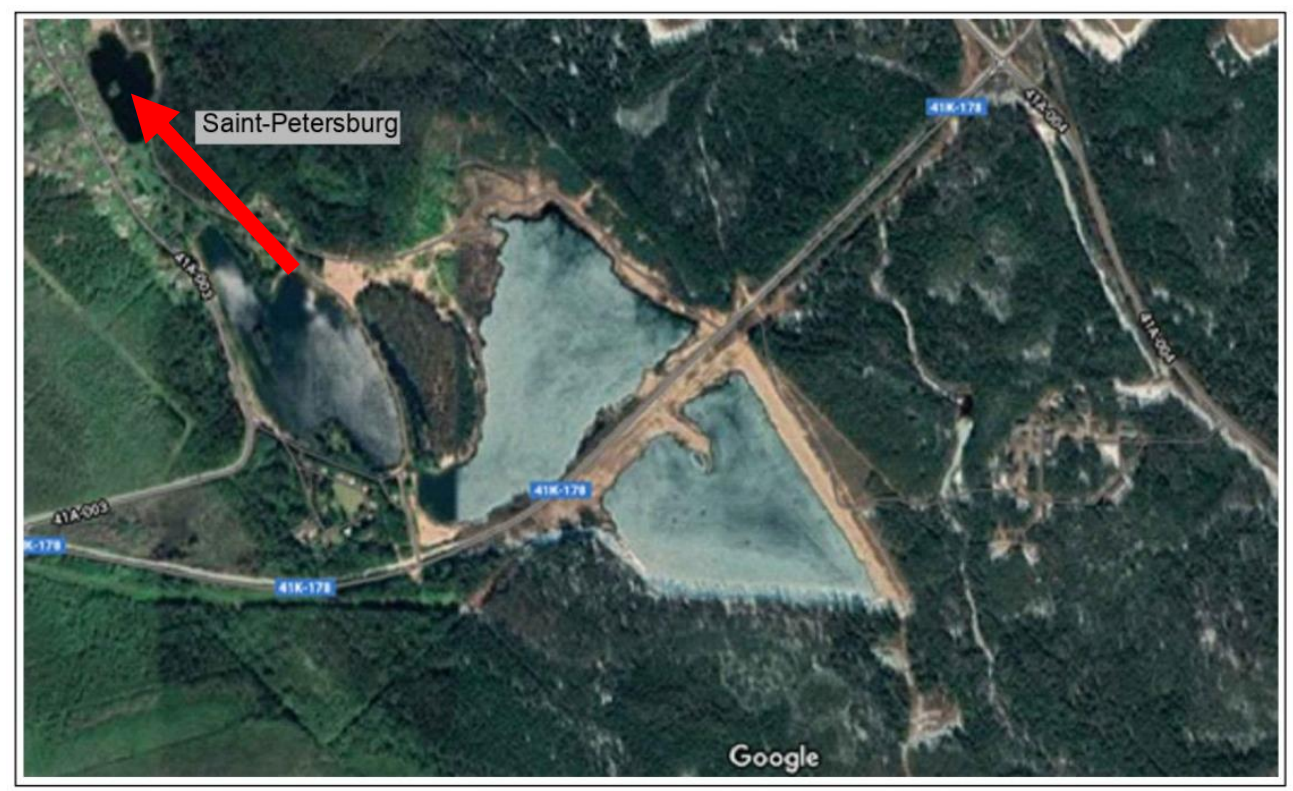

Fig. 1. A satellite image of the investigated sand quarries.

ATS is being studied in the territory adjacent to three quarries for the extraction of sand material, located in the immediate vicinity of the village of Shapki, Tosnensky district, Leningrad region. The area of the research object was about 150 hectares. The first development of sand quarries here began after the construction of the railway to the village of Shapki in 1912 [11]. The expediency of quarrying is confirmed by the geological map of 
the Quaternary sediments of the Leningrad, Pskov and Novgorod regions on a scale of 1 : $1,000,000$ [12]. The study area is confined to the sandy hills of the Shapkinsky-Kirsinsky ridge, composed of sandy loam and sand. Sand quarries are excavations filled with water and differ in the time of completion of operation. Sand mining stopped about 50, 40 and 3 years ago. During this period, forest [13] reforestation occurred on natural slopes with disturbed ecosystems of old abandoned quarries. Here Arenosols and Umbrisols were formed [14]. The "keys" method, remote and cartographic methods have used.

The aim of the work is to diagnose and characterize anthropogenic transformed SCS, assess the type and degree of transformation of the component composition, contrast and heterogeneity of SC, inter-component relationships, the shape and internal organization of SCS.

\section{Results and discussion}

There were revealed 43 contours of soils and soil combinations that bear signs of anthropogenic impact in the territory adjacent to the quarries. Non-soil formations (NSFs) were identified on the site of completely destroyed soils (Fig. 2).

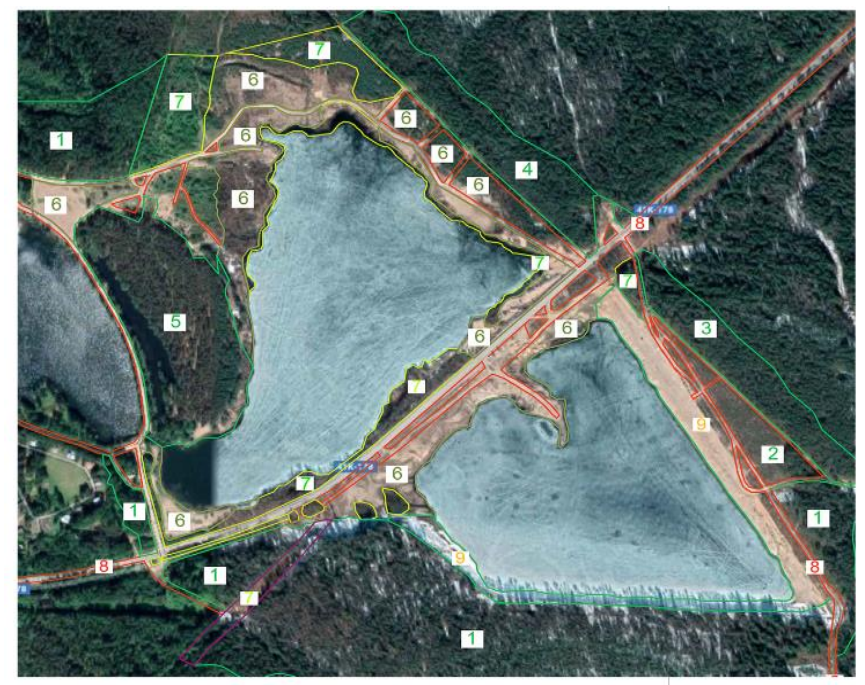

1 - Soil combinations: weakly changed natural soil, Turbic, Novic, Nudispodic

2 - Soil combinations: weakly changed natural soil, Novic, Nudispodic

3 - Weakly changed natural soil

4 - Soil combinations: weakly changed natural soil, Gleyic Podzol

5 - Soil combinations: weakly changed natural soil, Turbic, Novic

6 - Arenosols

7 - Folic Arenosols

8 - non-soil formations

9 - non-soil formations (rock)

Fig. 2. Contours of soils, soil combinations and NSFs.

It was revealed that the largest area is occupied by NSFs - 45\%. They are represented by asphalt and dirt roads, water-filled workings and excavations of sand. The soil combinations of turbocharged (Turbic), weakly changed natural soil, abraded (Nudispodic) and stratified (Novic) soils occupy $32 \%$ of the studied area. They are confined to territories adjacent to the excavations of sandy rocks and to roads.

Among the underdeveloped soils, Arenosols and Folic Arenosols (10\% and 7\%, respectively) are distinguished, which are distributed under forest plantations along the slopes of quarries and in areas experiencing not only direct impact (access roads to the quarry), but also indirect (recreation along the edges of water-filled quarries).

As a characteristic of the elementary initial unit of soil cover, the concept of elementary soil area (ESA) is used. An ESA is a contour consisting of soil belonging to any one classification unit of the lowest taxonomic rank, occupying space on all sides limited by other ESAs [1]. Each ESA is characterized by a specific shape, area and nature of the curved borders. The anthropogenic altered structure of the soil cover is represented mainly by the 
mid contour ESA. Large-contour ESA is less common and includes combinations of turbocharged, naturally slightly modified, abraded and stratified soils, as well as NSFs.

Elongated forms of habitats are characteristic of the soil combinations located along workings filled with water and roads. NSFs. In particular, the quarry area is isomorphic, and the NSFs under the roads are linear (Table 1). The average area of the contours varies from 0.3 ha to 6 ha. Strongly dissected ranges are represented by several contours of Folic Arenosols, confined to the edges of the quarry. The length of such contours significantly exceeds their width. Areas of other soil contours are mostly undifferentiated or weakly dissected.

The spatial organization of the soil adjacent to the quarry is an NSF located in the center of the study area and the ATS along the periphery [15]. Underdeveloped soils on sandy rock are formed along the edges of the quarry. Soil combinations of weakly altered natural soils, turbocharged and stratified, have been identified in territories adjacent to abandoned quarries where reforestation takes place.

For a detailed study of mining SCS, a key area of $100 \mathrm{~m}$ x $50 \mathrm{~m}$ on lake-glacial sands was laid, located near one of the quarries with the shortest term of exploitation. A dirt road with a roadside, a network of drainage ditches passes through the site, and there is a small quarry for the extraction of sand for individual needs, a fireplace.

Table 1. ESA forms of the study area

\begin{tabular}{|c|c|c|}
\hline $\begin{array}{c}\text { Number } \\
\text { of } \\
\text { contour }\end{array}$ & Contour & Form \\
\hline 1 & $\begin{array}{c}\text { soil combinations: weakly changed natural soil, } \\
\text { Turbic, Novic, Nudispodic }\end{array}$ & elongated \\
\hline 2 & $\begin{array}{c}\text { soil combinations: weakly changed natural soil, } \\
\text { Novic, Nudispodic }\end{array}$ & linear \\
\hline 3 & weakly changed natural soil & linear \\
\hline 4 & $\begin{array}{c}\text { soil combinations: weakly changed natural soil, } \\
\text { Gleyic Podzol }\end{array}$ & elongated \\
\hline 5 & $\begin{array}{c}\text { Turbic, Novic } \\
\text { Arenosols }\end{array}$ & elongated \\
\hline 6 & Focil Arenosols & elongated \\
\hline 7 & non-soil formations & linear \\
\hline 8 & non-soil formations (rock) & isomorphic \\
\hline 9 & & \\
\hline
\end{tabular}

The relief of the key site is well defined. The height difference is $2.7 \mathrm{~m}$. Modern vegetation is represented by undergrowth of spruce, birch, mountain ash, heather and lingonberry shrubs, in the grassy cover willow-tea, red fescue. A large-scale mapping was performed at the site, a site topography map, a soil map of the modern soil cover and a map of soil cover reconstruction for the period prior to anthropogenic impact were created [16]. 

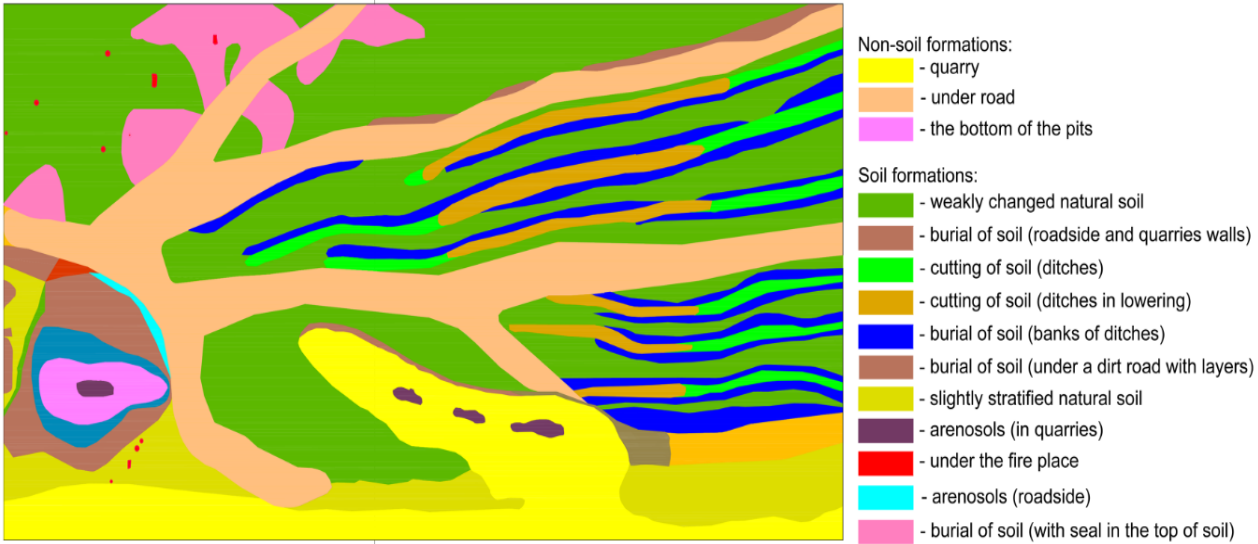

Fig. 3. Soil map of the key section of the sand quarry.

Quarries break the genetic links between the components, which leads to the transformation of SC from continuum to discrete. On the map of the reconstruction of the soil cover, it was revealed that before the anthropogenic impact, the soil cover was represented by two soils - Podzols and Entic Podzols.

During the field survey on the key site (Fig. 3, 4), 11 soil contours and 3 types of NSFs were identified (quarrying, a highway and the bottom of a shallow quarry for individual sand mining). In the key area, underdeveloped soils - Arenosols are confined to the curbs of a dirt road. The contour of Novic Podzols is revealed on the slopes of small quarries, along the edge of ditches. The bottom of small quarries is represented by Turbic Podzols. Nudispodic Podzols are formed by laying a network of drainage ditches. The topsoil is removed and material is deposited at the edges, forming a brow, on average, $0.4 \mathrm{~m}$ high.

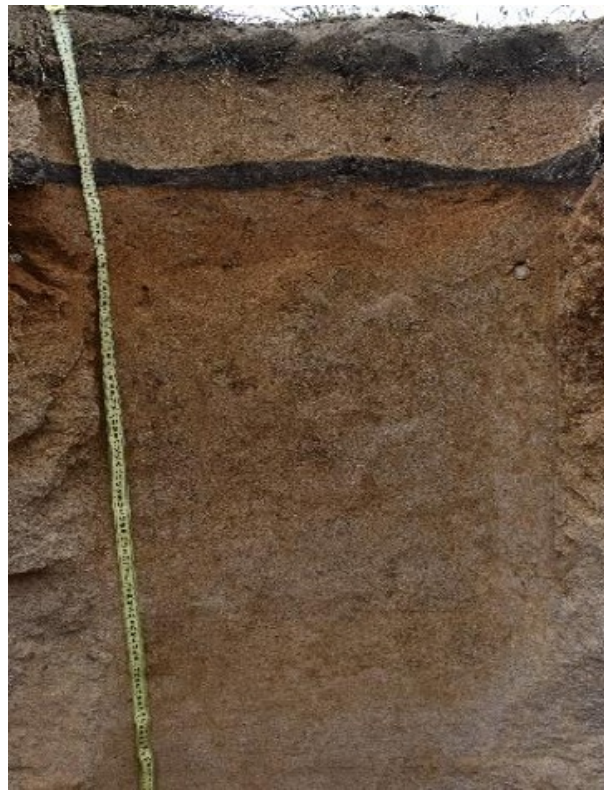

a)

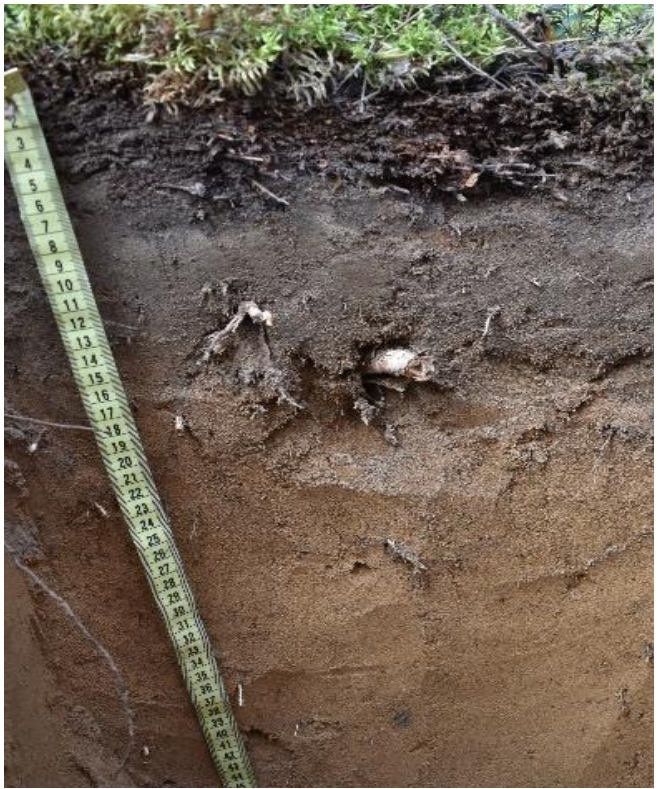

b) 


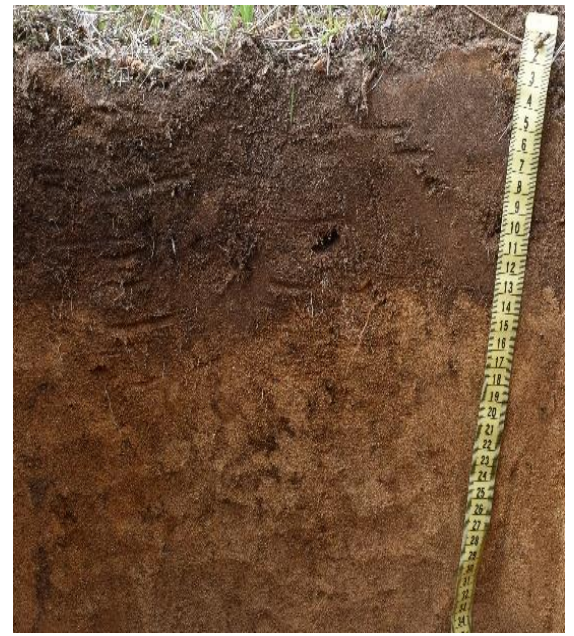

c)

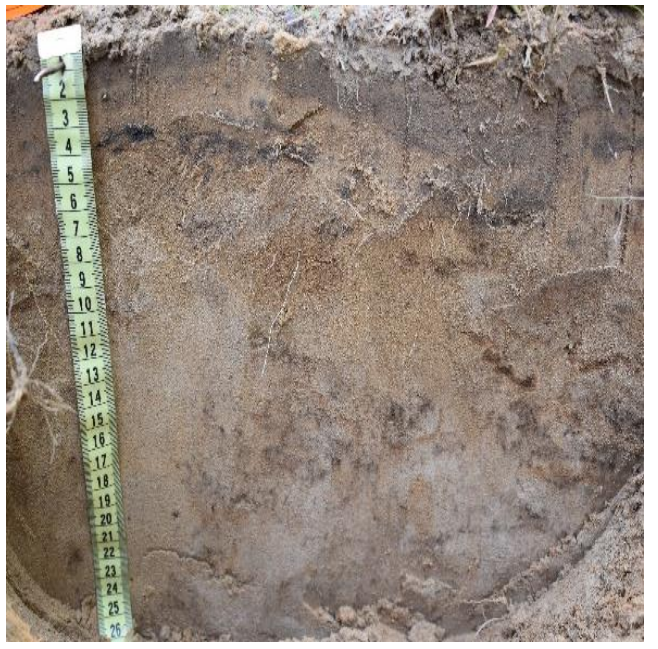

d)

Fig. 4. Soil profiles: a) stratified soil; b) slightly modified natural soils; c) abraded soil; d) underdeveloped soils on sandy rock.

ESA geometry of the key site is characterized by size, as well as shape and dissection. ESA of natural soils occupy the largest area (39\%). In addition, NSFs occupy a large area the road and sandy outcrops (32\%). ESA, represented by anthropogenic altered soils, account for only $17 \%$. The largest average sizes of ESA are characteristic of natural soil, the minimum - for stratified soils formed under bonfires. The areas of ESA are entirely determined by the size of the micro-relief to which they are confined. The largest areas of ESA are associated with a relatively flat position in the relief, those places between linear objects (ditches, roads), and the smallest are formed under the point foci of bonfires. ESA shape was estimated by the ratio of their largest to smallest axes. Of the 73 soil contours, 60 (82\%) are linear, 10 (14\%) elongated, and $3(4 \%)$ isomorphic.

The natural Podzols have been preserved in the area between the ditches, as well as at the opposite end from the quarry (Table 2). The surface of natural soil is covered with a thin layer of sand; it is not possible to isolate the diagnostic horizon.

Table 2. Distribution of contour areas on the key site

\begin{tabular}{|l|c|c|}
\hline \multicolumn{1}{|c|}{ Contour } & $\mathbf{m}^{\mathbf{2}}$ & \% of the total area of the key site \\
\hline NSF & 1654 & 33 \\
\hline Slightly modified natural soils & 1749 & 35 \\
\hline Stratified soil & 1216 & 24 \\
\hline Abraded soil & 361 & 7 \\
\hline Underdeveloped soils on sandy rock & 20 & 1 \\
\hline
\end{tabular}

\section{Conclusion}

Human activities in the region directly or indirectly affected not only soils, but also intercomponent genetic relationships that have developed over hundreds and thousands of years that determine the nature of SCS. When the bonds between the components are weakened or 
strengthened, the parametric characteristics of the SCS change to one degree or another (form, borders, contrast, composition, complexity).

The diagnostic feature of anthropogenic transformed soils formed as a result of mining is the spatial orientation of the soil cover. The central place is occupied by NSFs; peripheral (often concentric location) is characteristic of anthropogenic modified or newly created soils.

The development of sand quarries leads to increased differentiation of the structure of the soil cover, an increase in its contrast and the emergence of new combinations in place of homogeneous massifs. The scale of soil cover conversion is related to the size of the quarries. The complexity of the soil cover is illustrated by the key area. In the preanthropogenic period just two types of soil were identified on both localities. After placing the sand quarries, the number of contours has become 77. A significant proportion of the mining type of soil cover structure is occupied by NSFs.

\section{Acknowledgments}

This work was supported by the RFBR grant No. 19-04-01184.

\section{References}

1. V.M. Fridland, Struktura pochvennogo pokrova (Mysl', 1972) (rus)

2. V.V. Terleev, W. Mirschel, V.L. Badenko, I.Yu. Guseva, Eurasian Soil Science 50(4), 445-455 (2017)

3. V. Terleev, E. Petrovskaia, N. Sokolova, A. Dashkina, I. Guseva, V. Badenko, Y. Volkova, O. Skvortsova, O. Nikonova, S. Pavlov, A. Nikonorov, V. Garmanov, W. Mirschel, MATEC Web of Conferences 53, 01013 (2016)

4. O. Degtyareva, G. Degtyarev, I. Togo, V. Terleev, A. Nikonorov, Y. Volkova, Procedia Engineering 165, 1619-1628 (2016)

5. A. Nikonorov, V. Terleev, S. Pavlov, I. Togo, Y. Volkova, T. Makarova, V. Garmanov, D. Shishov, W. Mirschel, Procedia Engineering 165, 1741-1747 (2016)

6. V. Terleev, E. Petrovskaia, A. Nikonorov, V. Badenko, Y. Volkova, S. Pavlov, N. Semenova, K. Moiseev, A. Topaj, W. Mirschel, MATEC Web of Conferences 73, 03001 (2016)

7. Gosudarstvennaya geologicheskaya karta Rossijskoj Federacii. List O-35 (Pskov), (N35), O-36 (Sankt-Peterburg, FGBU "VSEGEI", 2010) (rus)

8. E.Yu. Suhacheva, B.F. Aparin, Pochvovedenie 9, 1140-1154 (2019)

9. C. Wenfang, S. Giulia, T. Paolo, Progress in Earth and Planetary Science 7, 2 (2020)

10. Z. Wang, A.M. Lechner, Y. Yang, T. Baumgartl, J. Wu., Elsevier BV in Science of The Total Environment 717 (2020)

11. T. Kiseleva, O. Mavrina, V sel'ce Dvorcovom v SHapkah. Kraevedcheskie zapiski (SPb, Nestor-Istoriya, 2014) (rus)

12. I.I. Krasnov, V.A. Selivanov. Geologicheskaya karta chetvertichnyh otlozhenij Leningradskoj, Pskovskoj i Novgorodskoj oblastej masshtaba (1966)

13. E. Abakumov, E. Gagarina, Pochvovedenie 3, 287-298 (2008)

14. World soil resource reference 2014, Food and agriculture organization of the United Nations (Rome, 2015) 
15. B.F. Aparin, M.A. Lazareva, Materialy Mezhdunarodnoj nauchnoj konferencii. I Nikitinskie chteniya "Aktual'nye problemy pochvovedeniya, agrohimii i ekologii v prirodnyh i antropogennyh landshaftah", 37-42 (2019) (rus)

16. P. Lagacherie, A.B. McBratney, Developments in soil science 31, 3-22 (2006) 